\title{
Impact of Climate Change on Food Availability-A Review
}

\author{
Belay Teressa \\ African Center of Excellence for Climate Smart Agriculture and Biodiversity Conservation, Haramaya University, Haramaya, \\ Oromia, Ethiopia.
}

How to cite this paper: Belay Teressa. (2021) Impact of Climate Change on Food Availability-A Review. International Journal of Food Science and Agriculture, 5(3), 465-470.

DOI: 10.26855/ijfsa.2021.09.017

Received: June 31, 2021

Accepted: July 27, 2021

Published: August 26, 2021

*Corresponding author: Belay Teressa, African Center of Excellence for Climate Smart Agriculture and Biodiversity Conservation, Haramaya University, Haramaya, Oromia, Ethiopia. Email: ensermu.b@gmail.com

\begin{abstract}
Food availability is when all people have sufficient quantities of food available on a consistent basis. Food availability is determined by food production and food trade. Climate change is a long-term change in the average weather patterns that have come to define Earth's local, regional and global climates. Major causes of climate changes are natural factors, including changes in the sun, emissions from volcanoes, variations in Earth's orbit and levels of carbon dioxide. Food availability and climate change impacts implies climate change and its impacts on food availability, including food chain activities from production to process, storage, distribution, and trade. These components are analyzed in FAO's national food balance sheets, among several others. Food balance sheets provide crucial information on a country's food system in three categories, namely domestic food supply, food utilization and per capita total food supply values. To overcome the problem climate change we should have to use a big benefits of reining in climate change, ask the government to continue climate action, take action in your community, donate to fight climate breakdown, power up on plants, top up your fitness, get your electricity from the wind and the sun and also take the train, not the plane.
\end{abstract}

\section{Keywords}

Climate change, Food availability, Impacts of climate change

\section{Introduction}

Food availability is when all people have sufficient quantities of food available on a consistent basis. Food availability is determined by food production and food trade [1]. It is the supply side of food security. Food security is a problem of distribution. Climate change can disrupt food availability, reduce access to food, and affect food quality. For example, projected increases in temperatures, changes in precipitation patterns, changes in extreme weather events, and reductions in water availability may all result in reduced agricultural productivity.

Food availability acts on individuals by modulating the rate at which they acquire caloric resources. For example, sea otters have high metabolic rates with little ability to store excess resources, so they must feed often [2].

Availability is one of the four components of food security and it addresses the supply side. The phrase refers to the physical inflow and presence of safe and nutritious food at a given time and in a given place (e.g., at a local market or in a country).

Food availability depends on healthy cultivated and natural land systems; thus it is widely recognized that ecosystemaware food security policies are necessary for sustaining food security in the long term. Governments can reinforce long-term productive agriculture by engaging in sustainable land use and responsible resource management. Specific policies for meeting these goals include: allocating land tenure rights and natural resource access, protecting soil and pollinators that are critical to crop growth, safeguarding forests that offer sources of food and contribute to water regulation, and allowing for ecosystem restoration services that ensure healthy ecosystems (IUCN, 2013). Liberia has been 
involved in a notable national initiative to advance policies and practices around land management. In 2006, the country passed the National Forest Reform Law and has since implemented a national Land Rights and Community Forestry Program that resulted in improved management of biologically significant forest (USAID, 2011).

The food availability decline (FAD) approach assumes that famines are caused by a sudden reduction of per capita food supply. It is usually triggered by natural disasters (drought, floods, pest infestation, etc.), wars, and epidemics that lead to a contraction of the food supply. As a consequence, food prices go up and people, who are not able to bear such an increase, consume less calories and nutrients. Consequently, the most vulnerable individuals start reducing their food consumption because of rising prices. In the case of prolonged exposition to a crisis, this may culminate in increased mortality due to starvation and infectious diseases. This model points out the insufficient production and availability of food as the main causes of famines and starvation. This approach implicitly assumes an equal division of the available food, but unfortunately, such an assumption fails to reflect reality. The FAD hypothesis implies that food security is essentially a matter of expanding food availability. As a solution, it argues to increase the supply and consequently the availability of food. This solution has been strongly criticized by Amartya Sen. However, he recognizes that famines can be caused by food availability decline and he also assumes this hypothesis for its entitlement approach.

Food availability focuses on the availability of sufficient quantities of food of appropriate quality, supplied through domestic production or imports. Evidence suggests that major crop yields across Africa and South Asia may decline by 8\% by 2050 as a result of climate change [3]. Yield changes in Africa are estimated as follows: maize (-5\%), sorghum $(-15 \%)$, millet (-10\%), and wheat (-17\%). In South Asia, sorghum and maize are predicted to have yield decreases of $11 \%$ and $16 \%$, respectively (Wheeler and von Braun, 2013). These declines in production levels will have consequences on food production and food availability. To manage the challenge of availability and achieve food security, strategies should aim to adapt farming systems to the impacts of extreme climate change and aim to reduce the environmental consequence of the agricultural sector. Farming systems can be adapted to climate change through the adoption of high-yielding crop varieties and sustainable soil management practices, the application of irrigation technologies that increase water use efficiency (such as drip irrigation), and the training of farmers. The adoption of integrated farming practices could reduce the use of external inputs, which would have positive consequences on the environment. Agro-ecological intensification can play an important role in this regard. For example, agro-ecological intensification can involve the substitution of chemical fertilizer by legumes, and the substitution of pesticides by biological pest control, e.g., using predators. In industrial countries, precision farming approaches can reduce wastage and environmental pollution [4]. Such practices can reduce the negative environmental externalities of agricultural farming systems, and they also can increase yields in the long run, and save substantial production costs. As farm input markets are not well developed in low-income countries, minimum dependence on external inputs and the use of ecological processes could help boost local production and ensure food availability.

Climate change is a long-term change in the average weather patterns that have come to define Earth's local, regional and global climates. These changes have a broad range of observed effects that are synonymous with the term. Main effects of climate changes are increased heat, drought and insect outbreaks, all linked to climate change, have increased wildfires. Declining water supplies, reduced agricultural yields, health impacts in cities due to heat, and flooding and erosion in coastal areas are additional concerns.

To stop climate change we should use: Ask the government to continue climate action, a big benefits of reining in climate change, take action in your community, donate to fight climate breakdown, power up on plants, top up your fitness, get your electricity from the wind and the sun and also take the train, not the plane.

Major causes of climate changes: These have been caused by many natural factors, including changes in the sun, emissions from volcanoes, variations in Earth's orbit and levels of carbon dioxide. As I have tried to review this paper also factors affecting food availability are Global food supply is not even. Some places produce more food than others and that physical factors (such as climate, soil quality and gradient) and human factors (such as technology) have historically controlled the quantity and type of food produced in any location. This review was conducted with the objective of to review the impact of climate change on food availability.

\section{Impacts of climate change on Crops}

Crops grown in the United States are critical for the food supply here and around the world. U.S. farms supply nearly $25 \%$ of all grains (such as wheat, corn, and rice) on the global market. Changes in temperature, atmospheric carbon dioxide $\left(\mathrm{CO}_{2}\right)$, and the frequency and intensity of extreme weather could have significant impacts on crop yields.

For any particular crop, the effect of increased temperature will depend on the crop's optimal temperature for growth and reproduction. In some areas, warming may benefit the types of crops that are typically planted there, or allow farmers to shift to crops that are currently grown in warmer areas. Conversely, if the higher temperature exceeds a crop's optimum temperature, yields will decline. Higher $\mathrm{CO}_{2}$ levels can affect crop yields. Some laboratory experiments suggest that elevated $\mathrm{CO}_{2}$ levels can increase plant growth. However, other factors, such as changing temperatures, ozone, 
and water and nutrient constraints, may counteract these potential increases in yield. For example, if temperature exceeds a crop's optimal level, if sufficient water and nutrients are not available, yield increases may be reduced or reversed. Elevated $\mathrm{CO}_{2}$ has been associated with reduced protein and nitrogen content in alfalfa and soybean plants, resulting in a loss of quality. Reduced grain and forage quality can reduce the ability of pasture and rangeland to support grazing livestock.

Especially floods and droughts can harm crops and reduce yields. For example, in 2010 and 2012, high nighttime temperatures affected corn yields across the U.S. Corn Belt, and premature budding due to a warm winter caused \$220 million in losses of Michigan cherries in 2012.

Dealing with drought could become a challenge in areas where rising summer temperatures cause soils to become drier. Although increased irrigation might be possible in some places, in other places water supplies may also be reduced, leaving less water available for irrigation when more is needed.

Many weeds, pests, and fungi thrive under warmer temperatures, wetter climates, and increased $\mathrm{CO}_{2}$ levels. Currently, U.S. farmers spend more than $\$ 11$ billion per year to fight weeds, which compete with crops for light, water, and nutrients. The ranges and distribution of weeds and pests are likely to increase with climate change. This could cause new problems for farmers' crops previously unexposed to these species.

Though rising $\mathrm{CO}_{2}$ can stimulate plant growth, it also reduces the nutritional value of most food crops. Rising levels of atmospheric carbon dioxide reduce the concentrations of protein and essential minerals in most plant species, including wheat, soybeans, and rice. This direct effect of rising $\mathrm{CO}_{2}$ on the nutritional value of crops represents a potential threat to human health. Human health is also threatened by increased pesticide use due to increased pest pressures and reductions in the efficacy of pesticides.

\section{Climate impacts affecting food production now}

Climate change poses not just one but a whole slew of challenges to farmers and to the larger communities that depend on them for food. From erratic precipitation to changing seasons, consider just these five key climatic changes and how they stand to affect food availability now and in the future:

1) More extreme weather can harm livestock and crops. Major storms have always devastated farms, whether from damaging winds during a storm, or erosion and landslides that can rear up even as the storm subsides. But now they're becoming even more common. In spring 2018, for example, unusually heavy rain and snow storms caused massive flooding across the U.S. Midwest, leaving some areas 10 feet deep in sand. In Nebraska alone, farmers lost an estimated $\$ 440$ million of cattle. As a result of these flooding conditions, many farmers had to delay spring planting. Delays in commodity crops like corn and soybeans aren't just stressful for farmers, either-they could lead to food price volatility and even potential food insecurity.

2) Water scarcity across the U.S. Southwest makes it more expensive and difficult to sustain crops and livestock. Drought is in the long-term outlook across the U.S. West, with declining snowpack making it more challenging to keep reservoirs full through summer. Lack of adequate water can easily damage or destroy crops, dry up soil, and threaten livelihoods. At 2014 to 2016 for example, California endured an estimated \$3.8 billion of direct statewide economic losses to agriculture as a result of drought.

3) Seasons aren't what they used to be. Growing seasons are starting earlier and getting hotter in a warming climate. A longer growing season, over time, could theoretically have some advantages, but it also presents more obstacles in the short term, such as an uptick in pest populations is possible, with more generations possible per year. Early spring onset can also cause crops to grow before the soil holds enough water and nutrients, or to ruin fruit crops that bud early and then experience later spring frost. Plus, warmer winters can affect other farming practices like grain storage.

4) Wildfire can devastate farms - even when the flames don't actually reach them. Ranchers across the West have recently seen major losses as a result of worsening fire seasons, from outright loss of life to charred grazing lands and decimated hay stocks. What's more, "secondary impacts" abound, from a smoky taint that can ruin wine, to the ordeal of keeping a farm operational when fires are raging nearby and evacuation orders seem just around the corner. All this also causes costs to mount given that the respiratory dangers of laboring in smoky, excessively hot conditions can force farms to send workers home in the height of harvest season.

5) Warmer weather and rising $\mathrm{CO}_{2}$ levels adversely affect food supply, safety and quality. According to a 2019 IPCC land use report, between 25 and 30 percent of the food produced worldwide is wasted, not all of it for the same reasons, in developed countries, for instance, consumers, sometimes seemingly with abandon, simply discards what they see as "excess" or "surplus" food. In developing countries, much of the waste is brought about by a lack of refrigeration as products go bad between producers and consumers. The IPCC report estimates that food waste costs about $\$ 1$ trillion per year and accounts for about 10 percent of greenhouse gas emissions from food systems. Meanwhile, some two-billion humans worldwide are overweight or obese even as nearly one billion are undernourished, highlighting the 
inefficiencies and inequities in food distribution.

In addition, rising temperatures can alter exposures to some pathogens and toxins. Consider: Salmonella, Campylobacter, Vibrio parahaemolyticus in raw oysters, and myco-toxigenic fungi, which can all potentially thrive in warmer environments. More carbon dioxide in the atmosphere also can decrease dietary iron, zinc, protein, and other macroand micronutrients in certain crops.

Now for the elephant still in the room: Food production isn't just being affected by climate change—it's actively contributing to climate change, too. According to IPCC's land use report, agriculture and other land uses comprise more than one-fifth of global $\mathrm{CO}_{2}$ emissions, creating a vicious cycle.

Food security according to 1996 World Food Summit is "a situation that exists when people at all times, have physical, social and economic access to sufficient, safe and nutritious food that meets their dietary needs and food preferences for an active and healthy life". Four dimensions of food security are defined as "availability" of enough and quality food, "access" to nutritious and adequate food by individuals, "utilization" of food to meet all socio-physiological needs and "stability" of availability, accessibility, and utilization of food [5, 6]. Considered "sustainability" of the overall food systems as a vital component in analyzing food security, on top of the four dimensions. Thus, considering sustainability is essential to achieve food security, which should also be considered as a "long-term time dimension” [7].

Additionally, the food availability and climate change impacts shed light on climate change and its impacts on food availability, including food chain activities from production to process, storage, distribution, and trade. These components are analyzed in FAO's national food balance sheets, among several others. Food balance sheets provide crucial information on a country's food system in three categories, namely domestic food supply, food utilization and per capita total food supply values [8]. Food availability, on the other hand, is the amount of total physical quantities of food available in a country or an area in the form of domestic production, import, exchange, processed and stocks after deducting the total exports.

\section{Climate change and food crops production}

The effect of the fertilization of carbon dioxide $\left(\mathrm{CO}_{2}\right)$ balances the adverse climate change effects and promotes plant growth [9]. However, several studies have argued against the positive effects of an increase in atmospheric $\mathrm{CO}_{2}$ levels. When the response of crops and the concentration of $\mathrm{CO}_{2}$ reach to a progressive saturation level, the effect of $\mathrm{CO}_{2}$ fertilization becomes minimal. Besides, the rise in atmospheric $\mathrm{CO}_{2}$ level continues, the temperature and rainfall will concurrently experience significant changes. Thus, the impact of $\mathrm{CO}_{2}$ is unable to stimulate agricultural and food crop productions [10]. Moreover, the effects of other factors such as diseases, pests or effects of adaptation were not considered in $\mathrm{CO}_{2}$ fertilization studies; hence, predictions may, therefore, be understated [11]. Climate change impacts on the hydrological cycle will intensify the prevalence of dry seasons and dry weather [12]. Exaggeration and recurring stormy weather patterns cause to change the hydrologic cycle and rainfall patterns, which will result in long-term impacts on world agroecosystem viability and food availability. In countries affected by water conflicts, such conflicts will also affect food production and accessibility of individuals [13]. Some countries will face severe droughts, while others will suffer excessive rains. These will lead about 63 per cent of the world's population to be hit with water stress by 2025 [14]. Coastal eutrophication in large marine ecosystems will increase by 20 percent by 2050 unless remedial actions are in place [15].

\section{Impacts on agricultural food processing, storage, and distribution}

Availability of agricultural food relies on activities such as processing, storage, and distribution of food locally, nationally or globally. Several studies indicate that food availability will affect negatively from production, storage, processing, and distribution due to supply chain failures and failures in food donation systems [16]. Countries in high latitude regions will benefit from climate change as the productions of grains expect to increase. Moreover, dry or cold weather in these countries allows the bulk handling of harvested grains without specific measures since humid weather will increase harvested grain humidity to 12 to 14 per cent, which is suitable for stable storage.

In contrast, climate change will have negative impacts on agricultural productivity in sub-Saharan Africa [17] and South Asia [18]. The tropical climate in the African region exposes post-harvest food products to pest attacks, micro-organisms, and diseases [19]. Inadequate drying facilities will render post-harvest food to be unsafe to eat due to microorganism infections (FAO, 2008a). High frequency and intensity of precipitation due to climate change in countries with inadequate road systems will affect the distribution system and infrastructure [20]. Investments in logistics and food storage technology, transportation networks, food waste management [21] and minimizing wastage in food commodities [22] are crucial in most developing countries. 


\section{Conclusion and Recommendation}

Food availability is when all people have sufficient quantities of food available on a consistent basis. Food availability focuses on the availability of sufficient quantities of food of appropriate quality, supplied through domestic production or imports. Climate change is a long-term change in the average weather patterns that have come to define Earth's local, regional and global climates. The reviewed paper implies that the major causes of climate changes are natural factors, including changes in the sun, emissions from volcanoes, variations in Earth's orbit and levels of carbon dioxide. Food availability and climate change impacts implies climate change and its impacts on food availability, including food chain activities from production to process, storage, distribution, and trade. These components are analyzed in FAO's national food balance sheets, among several others. The major impacts of climate change on food production now days are more extreme weather can harm livestock and crops; water scarcity makes it more expensive and difficult to sustain crops and livestock, seasons are not what they used to be, wildfire can devastate farms and warmer weather and rising $\mathrm{CO}_{2}$ levels adversely affect food supply, safety and quality.

To overcome the problem of climate change which affects food availability, we should have to use a big benefits of reining in climate change, ask the government to continue climate action, take action in your community, donate to fight climate breakdown, power up on plants, top up your fitness, get your electricity from the wind and the sun and also take the train, not the plane. Therefore, food availability will be secured if and only if the climate change problems solved sustainably.

\section{References}

[1] FAO. (2005, May 23-26). Background document of special event on impact of climate change, pests and diseases on food security and poverty reduction.

[2] Costa, D. P. and Kooyman, G. L. (1982). Oxygen consumption, thermoregulation and the effect of Fur oiling and washing on the sea otter. Canadian Journal of Zoology, 60(11), 2761-2767.

[3] Wheeler, T. and von Braun, J. (2013). Climate change impacts on global food security.

[4] Godfray, H. C. J. (2015). The debate over sustainable intensification. Food Security, 7(2), 199-208

[5] FAO. (2016). The state of food and agriculture: Climate change, agriculture and food security. Rome, Italy: Author ISBN 978-92-5-109374-0.

[6] Timmer, C. P. (2017). Food security, structural transformation, markets and government policy.

[7] Berry, E. M., Dernini, S., Burlingame, B., Meybeck, A., and Conforti, P. (2015). Food security and Sustainability.

[8] Mayo, R. (2008). Towards a simplified food balance sheet. Agenda item 10c, (APCAS/08/14) Asia and Pacific commission on agricultural statistics, twenty-second sessions, Kuching, Malaysia.

[9] Darwin, R. and Kennedy, D. (2000), Economic effects of CO2 fertilization of crops: Transforming Changes in yield into changes in supply.

[10] Tubiello, F. N., Soussana, J. F., and Howden, S. M. (2007). Crop and pasture response to climate Change, Proceedings of the National Academy of Sciences of the United States of America, 1.

[11] Vermeulen, S. J., Campbell, B. M., and Ingram, J. S. I. (2012). Climate change and food systems.

[12] Kundzewicz, Z. W., Mata, L. J., Arnell, N. W., Doll, P., Kabat, P., Jiménez, B., and Shiklomanov, I. A. (2007). Freshwater resources and their management, In M. L. Parry, O. F. Canziani, J. P. Palutikof, P. J. van der Linden, and C. E. Hanson (Eds.), Climate change 2007: Impacts, Adaptation and vulnerability Contribution of working group II to the fourth assessment, Report of the intergovernmental panel on climate change.

[13] Gleick, P. H. (1993). Water in crisis: A guide to the world's fresh water resources. New York, NY: Oxford University Press.

[14] Arnell, N. W. (1999). Climate change and global water resources, Global Environmental Change, 9.

[15] United Nations. (2018). The sustainable development goals report 2018. New York, NY: Author.

[16] Chodur, G. M., Zhao, X., Biehl, E., Mitrani-Reiser, J., and Neff, R. (2018). Assessing food system, Vulnerabilities: A fault tree modeling approach.

[17] Blanc, E. (2012). The impact of climate change on crop yields in sub-Saharan Africa. American Journal of Climate Change.

[18] Lobell, D. B., Burke, M. B., Tebaldi, C., Mastrandrea, M. D., Falcon, W. P., and Naylor, R. L. (2008). Prioritizing climate change adaption needs for food security in 2030. Matuschke, I. (2009). Rapid urbanization and food security : Using food density maps to identify future food security hotspots Rapid urbanization and food security : Using food density maps to identify future food security hotspots. Pp. 1-15.

[19] Nukenine, E. N. (2010). Stored product protection in Africa: Past, present and future. Proceedings of $10^{\text {th }}$ international working conference on stored product protection, 
[20] Hendrix, C. S. and Salehyan, I. (2012). Climate change, rainfall and social conflict in Africa Journal Jonathan Mockshell, Ma. Eliza J. Villarino, in Encyclopedia of Food Security and Sustainability, 2019

[21] Abbade, E. B. (2017). Availability, access and utilization: Identifying the main fragilities for Promoting food security in developing countries.

[22] Godfray, H. C. J., Beddington, J. R., Crute, I. R., Haddad, L., Lawrence, D., Muir, J. F., and Toulmin, C. (2010). Food security: The challenge of feeding 9 billion people. 